\title{
Advancing the research agenda on food systems governance and transformation
}

Caroline van Bers, Aogán Delaney, Hallie Eakin, Laura Cramer, Mark Purdon, Christoph Oberlack, Tom Evans, Claudia Pahl-Wostl, Siri Eriksen, Lindsey Jones, Kaisa Korhonen-Kurki, Ioannis Vasileiou ${ }^{1}$

As published in Current Opinion in Environmental Sustainability, 39, 94-102.

\begin{abstract}
The food systems upon which humanity depends face multiple interdependent environmental, social, and economic threats in the $21^{\text {st }}$ Century. Yet, the governance of these systems, which determines to a large extent the ability to adapt and transform in response to these challenges, is under-researched. This perspective piece synthesises the findings of two recent reviews of food systems governance and transformations and proposes a comprehensive research agenda for the coming years. These reviews highlight the influence of governance on food systems, methodological obstacles to explaining the effectiveness of governance in realising food sustainability, and conditions that have historically supported food system transformations. We argue that the following steps are key to improving our knowledge of the role of governance in food systems: (1) developing more comparable research designs for building generalisable explanations of what governance elements are most effective in realising food systems goals; (2) using the lens of polycentricity to help disentangle complex governance networks; (3) giving greater attention to the conditions and pre-conditions associated with historical food system transformations; (4) identifying adaptations that strengthen or weaken path dependency; and, (5) focusing research on how transformations can be supported by institutions that facilitate collective action and stakeholder agency.
\end{abstract}

Keywords: governance, food systems, transformation, food security, sustainability, adaptation, climate change

${ }^{1}$ Author affiliations at the end of the manuscript 


\section{Introduction}

The future of the world's food systems is one of the primary concerns of the 21 st century. Food systems, as globally networked and interdependent human-environmental systems, are threatened by long-term trends in resource availability and degradation, demographic shifts affecting consumption patterns and labour availability, and climatic change among other concerns [1]. Global food production and consumption patterns and practices are also primary drivers of soil erosion and land use change, biodiversity loss, alterations in global biochemical cycling, greenhouse gas emissions and water quality degradation [2-4]. Furthermore, food systems continue to exhibit significant inequity: while globalization has vastly improved food access for a majority, over 800 million people still suffer chronic food insecurity [5]. Finally, food systems are altering the manifestation of malnutrition around the world, with stunting and overweight now co-existing within the same country and even the same individual [6]. Together, the threats to and challenges posed by global food systems demand transformative strategies.

While considerable attention has been given to the need for technological innovation, changes to production practices and shifts in consumption patterns, issues of food system governance in support of more sustainable food systems is a relatively recent focus of research $[9,10]$. The concept of a "food system" as a subject of analysis has become increasingly prevalent over the last 20 years, as awareness has grown about global social and environmental externalities, complex and often distal political-economic, cultural and ecological interactions that drive food system dynamics and the linkages between food, agriculture and global environmental change [3]. In other words, food systems are now recognized as social-ecological systems: characterized by interdependent, multi-scalar elements linked across space and time [3]. The complexity of such systems makes them subject to non-linear dynamics, unpredictability and surprise. Nevertheless it is only recently that the governance of such systems has been explicitly addressed in food system research [11-15]. Governance is implicitly addressed as the "back story" to many food system discussions and explicitly addressed in relation to specific aspects of various food systems activities, spaces and actors [11,13,14,16-18], but not often for food systems as a whole [11]. Governance of food systems is difficult to address because the system is multi-dimensional: what is being governed ranges from natural resources (soil, water, land, oceans) to commodities (energy, fish, corn, palm oil), products (bread, corn syrup), and socio-economic aspects (communities, livelihoods, labour, finance). This raises critical issues about which governance arrangements are best suited to cope with the complex dynamics and flows operating simultaneously at local, regional and global levels.

In this paper we understand food systems as the "activities and outcomes ranging from production through to consumption, which involve both human and environmental dimensions" [3], for the purpose of achieving food security, defined as when "all people, at all times, have physical and economic access to sufficient, safe and nutritious food to meet their dietary needs and food preferences for an active and healthy life" [19]. Governance in the context of food systems "refers to processes and, actor constellations and institutions that shape decisionmaking and activities related to the production, distribution and consumption of food" [8]. "G[g]overnance is 
more than the formal functions of government but also includes markets, traditions and networks, and non-state actors such as firms and civil society" [20] highlighting how agency and power relations between a multitude of actors are key to any transformative change in food systems. Transformation refers to "a change in the fundamental attributes of natural and human systems" [7]. According to the IPCC [7], a transformation involves fundamental changes to practices, values and governance systems. A transformation of a governance system refers to "structural change in several interdependent system components (e.g., institutions, actor networks) and change in the overall logic of the system, i.e., in dominant cultural cognitive institutions" [8].

As with many coupled social-ecological systems, food systems entail complex interactions between biophysical and social elements spanning scales and geographies, linking individuals and societies across the globe [21-25]. But food systems exist, persist and change in response to human ingenuity, needs and intervention [26]. By extension, the increasing quest for enhancing the sustainability of food systems problematizes processes of transformation in food systems [27]. In this regard, diverging views on what precisely constitutes food systems sustainability is one of the important contemporary governance challenges $[9,28]$.

At the core of this paper is an examination of the key insights, methodological considerations and theoretical debates associated with the role of governance in food system transformations, indicators of how food systems transformations are governed, and implications for future research. These issues were addressed through two systematic reviews undertaken by experts from a range of disciplines for the CGIAR Research Program on Climate Change, Agriculture and Food Security (CCAFS). The first review, the 'Transformations Review', focused on empirical studies of governance of food system transformations and transformations in food systems governance to better understand how and under what conditions transformations occur, given the rising concern that transformation in food system structure, consumption patterns, food production practices are needed [29]. The second, the 'Indicators Review', sought to identify a core set of indicators for evaluating the effectiveness of governance in realising food systems outcomes. The results of the individual reviews have been published separately $[8,30,31]$, while the main findings are summarised in Table 1 . An expanded version of this summary accompanies this article as supplementary material. In this paper we synthesise results from both systematic reviews to highlight theoretical and methodological challenges common in the literature and propose an agenda for future research on the topic. The reviews suggest that ways in which food systems are governed play a critical role in stimulating or hindering transformations. Drawing on these key insights into food systems governance and associated transformations, we identify core questions and themes associated with transformations in food systems governance to be explored in future studies. 
Table 1. Main synthesised results of the Transformations and Indicators Reviews

\section{The importance of food system governance}

- Although governance is rarely acknowledged as a driver of change, the Transformations Review points to governance as an important condition for transformations.

- Governance is considered to be an increasingly critical element of food systems dynamics, as the role of nation-states, particularly in the Global North, has declined relative to corporate/transnational and civil society actors.

- Despite shifts in governance that make transformations possible, considerations of how to assess and design governance of food systems as a whole, embracing production, distribution and consumption, are still scarce in science and policy.

- Moreover, in order for governance to facilitate transformation to sustainable food systems some aspects of governance itself must change and there is much to be learned from cases of effective food system governance.

\section{What constitutes effective governance of food systems?}

- Despite efforts to explore characteristics of effective food system governance, an assessment of the relative effectiveness of different governance elements remains elusive due to research methods employed and a lack of dialogue across disciplines.

- Many studies assess governance in terms of how reforms are implemented rather than examining the food security, equity or environmental outcomes of such reforms.

- This is compounded as different actors express different ideas about what the desired outcomes of food systems should be.

- These features hinder cross-site analysis and prevent generalisable conclusions.

\section{Transformations in governance systems}

- The most common trigger of transformations in food systems was found to be a crisis in the form of a shock or increasing pressure resulting in governance or technological innovations.

- Beyond triggers, access to economic and social resources is often necessary for facilitating (or hindering) transformations in governance, as are the effectiveness of formal institutions, and how locked in the reigning paradigm is.

- Institutions for collective action stand out in both of the analyses as a means to manage food systems sustainably and initiate transformations, in particular, to achieve greater equity.

\section{New directions and future research}

In this section, we propose a set of key questions relating to governance and transformations in practice, as well as theoretical and methodological considerations, that require attention in future research. It builds on a synthesis of the two reviews and the ensuing discussions among the researchers involved. 


\section{- What methodological advances can help explain the effectiveness of food systems governance?}

If the research community wishes to make evidence-supported claims of how food systems can be most effectively governed for sustainability, governance should be evaluated in terms of its effects on a variety of food system outcomes. Greater theoretical coherence and methodological consistency in terms of what constitutes food systems governance and how it is measured is required to facilitate more powerful and generalizable explanatory findings. The Indicators Review proposed a core set of measures for future studies (see [30,31]), but challenges remain: for example, the disproportionate focus on food production activities compared to distribution or consumption (partly reflecting disciplinary foci), and the tendency for research designs to collect data only at one given scale. A next step is therefore to improve research across food system activities and foster greater cross-disciplinary engagement. This might include interactions and feedback among food processing, distribution and consumption, and how the governance of such interactions affect food systems outcomes and transformations. More attention is also needed to shed light on agency in governance change, and in particular, to understand how such agency is practiced within the complexity of relations between formal and informal actors, institutions and processes. Here, insights from supply chain research and organizational theory may aid in understanding how change in governance towards more sustainable outcomes comes about, what actors mobilize such change and what configurations of institutions result (e.g., [32-34]). It is also important that new research is informed by, as well as read and taken up in the context of international and interdisciplinary networks of practice in order to benefit from the variety of geographic and disciplinary backgrounds that are required to ensure the breadth of leading edge research needed to tackle the issue. What actors have agency and influence in food system governance differs in distinct cultural and political contexts and historical moments [25]. While we address historical approaches more fully below, insights are needed from a broader geographic and epistemological scope of scholarship, particularly from the Global South where food insecurity is more prevalent, and food system dynamics and outcomes are tightly coupled with social, political and environmental change [35] that are different in important ways from those in developed countries. Future empirical studies need to pay particular attention to whose agency is mobilised in which situations and the power relations through which particular actors are authorised to make which decisions, as demonstrated by daily practice, hence examining the power and politics taking place within governance systems [36,37].

How are developing countries different? Drawing on the literature of comparative politics, especially Kahn's [38] political settlements framework in comparative political economy, we submit that low levels of economic development influence the political dynamic in developing countries in important ways that have important implications for food systems governance. Economic scarcity and an underdeveloped private sector have the counterintuitive effect of concentrating political and economic power in the state, despite relatively weak state capacity, while simultaneously driving politics into the informal sector. The implication is that assumptions of pluralist theories of public policy and governance that underwrite much food policy research might be misplaced. Pluralism tends to assume that political power is widely dispersed amongst various interest groups active in a 
formal policy subsystem and held in check by democratic institutions [39]. While pluralism may offer a fair characterization of environmental policy deliberations in Western liberal democracies (see [40]), we find it inappropriate for developing countries. The policy studies literature remains open to the critique that it is informed by the experience of Western liberal democracies in ways that frustrate transferability to other countries $[41,42]$. We are encouraged that scholars from the Global South are increasingly developing novel theories of governance (for example, $[43,44]$ ) and encourage their greater involvement in empirical and theoretical research into food systems governance. By challenging assumptions of traditional policy and governance theory, research in developing countries promises to produce some of the most interesting and cutting-edge insights.

Additionally, the importance of understanding variation in structure and agency in food system transformations between different parts of the world raises dilemmas for traditional quantitative policy approaches. The governance elements of interest are often difficult to capture with quantifiable measures, and may be better observed through qualitative and multi-method approaches. There is an emerging consensus that comparative researchers can now legitimately conduct causal explanatory research using methods such as process tracing [4547], qualitative comparative analysis [48-51] and systematic process analysis [52]. In particular, Purdon [53] and Purdon and Thornton [54] have highlighted methods from the field of comparative politics which may facilitate better generalisation, particularly qualitative and multi-methods approaches for small-N comparative analysis [47, $55-58]$.

- What can theories of polycentricity contribute to the understanding of how governance affects food systems?

Food systems are rarely governed as systems, but they involve complex networks of actors, activities, and flows that demand system approaches [25]. Food systems extend beyond the jurisdictional scope of traditional governance institutions, and at the same time, activities and impacts can change dramatically within a single jurisdiction (e.g. between cities and peri-urban hinterlands). As noted, governance of food often entails governance of natural resources, commodities, and socio-economic issues, typically involving a vast set of institutions and mechanisms. Work in sustainability science has provided new approaches to governance that may prove fruitful in the food system space (e.g., [59,60]). For example, theories of polycentricity could be a starting point to improved understanding of food system governance, though we found little evidence of this in the reviews. The polycentricity lens might allow researchers to disentangle complex systems of networked governance. Governance systems are considered polycentric if they (1) organize decision-making in multiple, independent decision-making units and (2) involve mechanisms for cooperation, competition and conflict resolution [61,62]. The proliferation of co-existing governance initiatives and actors (e.g. state regulations in and across multiple sectors and levels, certification schemes, regional cooperatives and local food initiatives) indicates the presence of multiple decision-making units, whereas a lack of coordination between them indicates fragmentation. Such an analysis might be used to partly explain low levels of governance effectiveness in relation 
to sustainability outcomes [63]. Consistent with this view, the Transformations Review found that transformations in the structure of actor networks and coordination mechanisms accompanied or preceded the majority of cases of food system transformations towards enhanced sustainability.

Furthermore, the polycentricity lens can highlight and explain the significance of specific attributes of governance systems. For instance, governance systems in which decision-making centres exist at different levels as well as across jurisdictions are considered more likely to adapt effectively to social and ecological change because feedback loops can relay information between levels and foster improved decision-making [64]. Adapting to change is a first step towards food system transformation. Attributes that enhance adaptive capacity also increase the capacity for transformative change. Governing transformations of complex social-ecological systems in general, and food systems in particular is a combination of processes of self-organization, social learning and purposeful design. Distributed decision-making also facilitates the observation, analysis and wider dissemination of local-level impacts and outcomes of food system activities, enabling flows of information and knowledge to create bridges across geographies, enhancing accountability in globalized food systems and creating learning opportunities [25]. Decentralized nodes of decision-making supports the ability to experiment and employ diverse institutional solutions, in particular if mechanisms for deliberation, learning, accountability and conflict resolution are included [65-67]. Approaches such as networks of action situations [68,69] and ecology of games [70] may be useful ways of analysing the effectiveness of complex polycentric governance arrangements in food systems.

\section{- What can we learn from historical food system transformations and opportunities for shifting path dependencies?}

Transformations can take time, and may only be perceptible in retrospect. In addition to considering geographical variation in food system governance, history can thus provide critical insights into the conditions in which transformations occurred, the precipitating factors, key actors, drivers and consequences of such structural changes. Technological innovation, such as the coupling of fertilizer and improved hybrid seeds in the Green Revolution, for example, can precipitate shifts in the role and influence of food system actors as well as transformation in the institutions that govern resource use [71,72]. In other cases, an environmental shock or crisis (what many experts describe as "critical junctures") may trigger processes of demographic and social change, ultimately restructuring a nation's food system. Research making use of historical institutional approaches have highlighted how a variety of today's policy issues find their origin in critical historical moments that create their own path-dependent political processes that are resistant to change. These include the type of colonialism that developing countries experienced (e.g., [73]) but examples can be also found in the developed world including, relevant to food systems governance, the Irish Potato Famine of the 19 ${ }^{\text {th }}$ century [74] as well as, relevant to renewable energy policy, the energy shock of the 1970s [75]. 
History can inform current and future scholarship by signalling the contextual and immediate factors that have played key roles in altering food system structure, governance and outcomes. Less clear, however, is how such findings can be used to intentionally design, steer or engineer complex food systems towards more sustainable states, and what capacities and conditions would be needed if such steering is possible. The possibility of crafting policy to catalyze cumulative, progressive political trajectories moving forward is attracting considerable attention in the climate policy studies literature [76,77].

Our Transformation Review found that access to resources, effectiveness of formal institutions and ability to overcome lock-in effects are especially important for stimulating (or, conversely, hindering) food system transformations. However, far more work is needed to compile lessons to inform future food system change, especially empirical research from developing countries. What does it take to shift a food system from its present historical institutional pathway? For example, research is required on constellations of conditions and their interdependencies: if only one condition for transformation is fulfilled (e.g. availability of financial resources), what does this imply for the design of processes to support transformative change?

Understanding the synergies, sequencing and differential importance of distinct pre-conditions, and the ways in which existing capacities can be mobilized to overcome barriers to change remains an important research agenda. Our reviews suggest a need for greater research attention in food system governance to analytical distinctions in the policy literature, particularly those between Lindblom's incremental policy change [78] and Hall's [79] paradigmatic policy change as well as cumulative and non-cumulative policy change [80,81]. However, we should also remain alive to the utility of analytical categories such as the distinction in the resilience literature between fast versus slow variables $[82,83]$. Such a framework could help to explain how responses to short-term shocks can deepen path dependency and undermine adaptation to longer-term environmental change (e.g. [84]). In addition, it is of course important to recognize the unique policy contexts of developing countries. Even Lindblom would concede that progressive incrementalism might be limited to conditions of stable political pluralism that characterize developed countries (see [85]).

\section{- What influence does collective action have on governance of food systems, and can institutions stimulate collective action to bring about transformations?}

Collective action can be a highly effective approach to managing food systems sustainably and deserves more attention. A comprehensive study of transformations arising from collective action and the associated governance processes would be a highly valuable contribution to food system research. This issue is particularly salient given the proliferation of social movements and associated organizations (e.g., Via Campesina and food sovereignty, the "local food" movement, etc.) that are shaping social and institutional responses at various levels of organization and with disparate implications around the world. 
Accordingly, one of the most important roles of governance is to facilitate and support transformative practices and collective actions when they emerge. There is, therefore, a need to examine how governance actors exercise their agency, such as through learning (e.g. [86-88]), self-organising outside of state-embedded structures (e.g. $[84,89])$, and mobilizing their capacity and will to anticipate threats and undergo self-transformation in response (e.g. [90,91]). Crucially, we have limited examples of how agency is exercised; much of the literature focuses on actions taken and institutional outcomes rather than the mechanisms and conditions that enable the exercise of agency [92]). Future research therefore needs to combine observational data on governance structures with narrative accounts of actions, in order to reflexively inform and make sense of how collective action and stakeholder agency can initiate and facilitate adaptations and transformations [93].

\section{Conclusions}

Meeting the complex challenges of satisfying global food demands, fairly and equitably, while also reversing the ecological toll food systems exact on the planet will require greater focus on the role of governance in food systems transformations. In this paper we synthesised the findings from two CCAFS reviews on food systems governance and transformations and pointed towards a set of priority issues to be addressed in future research. In our reviews we identified the following key issues in food systems governance and research:

- The role of governance is under-represented in food systems research, and particularly in relation to food system transformation.

- Past research often had a specific disciplinary or "activity-oriented" (e.g., production, processing, consumption) focus rather than an integrated, systemic perspective and overlooked the complexity of food systems, and we should accelerate the movement within research [94-98] to focus more on an integrated food systems approach.

- Food system change appears to be related to changes in governance rather than simply policies: more attention needs to be given to understanding the preconditions, processes and mechanisms as well as the outcomes of governance change in relation to sustainability.

- Existing governance arrangements and the historical and current contexts in which they operate are likely to create distinct possibilities for food system change.

- Institutions for collective action can initiate food system transformation.

Addressing these issues requires a change in focus in how food systems governance and transformations is researched, including recognizing a greater diversity of voices, ideas and experience in knowledge generation. Specifically, we have outlined a five point agenda for the next generation of research:

- Focus on methodological advances including those giving more attention to food system outcomes

- Use the polycentricity lens for understanding complex systems of networked governance

- Test the context-specific conditions and preconditions for sustainability transformations.

- Identify the types of adaptations that strengthen or weaken path dependency 
- Examine how the agency of a diversity of actors is exerted (or not) and how agency can be supported to engender sustainability transformations

The CCAFS-funded reviews on which this commentary is based arrived at these conclusions thanks to the various backgrounds in the interdisciplinary and intercontinental group. We would suggest that this research agenda be taken up in similar such networks as tackling a complex and multi-faceted issue such as food systems governance requires dialogue between a diversity of scientific approaches. These steps will help to build a body of research that can better inform how changes in governance and agency can foster transformative change that addresses resource depletion, inequality, environmental integrity and social change and hence support climateresilient development.

\section{Affiliations}

Caroline van Bers, Institute of Environmental Systems Research. Osnabrück University, Faculty of Mathematics FB6, 49069 Osnabrück, Germany (Corresponding Author). Email: cvanbers@uos.de.

Tel: +495419692505

Aogán Delaney, Independent consultant, Luxemburg. Email: aogan.delaney@gmail.com

Hallie Eakin, School of Sustainability, Arizona State University. Email: Hallie.Eakin@asu.edu

Laura Cramer, CGIAR Research Program on Climate Change, Agriculture and Food Security (CCAFS). Email L.Cramer@cgiar.org

Mark Purdon, Département de stratégie, responsabilité sociale et environnementale de l'École des sciences de la gestion de l’Université du Québec à Montréal (ESG UQAM). Email : purdon.mark@uqam.ca

Christoph Oberlack, Centre for Development and Environment, University of Bern. Email christoph.oberlack@cde.unibe.ch

Tom Evans, Department of Geography, Indiana University Bloomington. Email: tomevans@email.arizona.edu

Claudia Pahl-Wostl, Institute of Environmental Systems Research, Osnabrück University. Email: cpahlwos@uos.de

Siri Eriksen, Department of International Environment and Development Studies, Norwegian University of Life Sciences. Email: siri.eriksen@nmbu.no 
Lindsey Jones, Grantham Research Institute on Climate Change and the Environment, London School of Economics and Political Science. Email: L.Jones3@1se.ac.uk

Kaisa Korhonen-Kurki, Helsinki Institute of Sustainability Science, University of Helsinki. Email: kaisa.korhonen@helsinki.fi

Ioannis Vasileiou, World Bank. Email: ivasileiou@worldbank.org

\section{Acknowledgements}

This work was implemented as part of the CGIAR Research Program on Climate Change, Agriculture and Food Security (CCAFS), which is carried out with support from CGIAR Fund Donors and through bilateral funding agreements. For details, visit https://ccafs.cgiar.org/donors. The views expressed in this document cannot be taken to reflect the official opinions of these organizations. This work was supported by the U.S. National Science Foundation (grant numbers SES-1360421, SES-1360463 and BCS-1534544).

\section{References}

1. Connolly-Boutin L, Smit B: Climate change, food security, and livelihoods in sub-Saharan Africa. Reg Environ Change 2016, 16:385-399.

2. Rockström J, Williams J, Daily G, Noble A, Matthews N, Gordon L, Wetterstrand H, DeClerck F, Shah M, Steduto P, et al.: Sustainable intensification of agriculture for human prosperity and global sustainability. Ambio 2017, 46:4-17. 3. Ericksen PJ: Conceptualizing food systems for global environmental change research. Global Environmental Change 2008, 18:234-245.

4. Rockström J, Steffen W, Noone K, Persson A, Chapin FSI, Lambin E, Lenton T, Scheffer M, Folke C, Schellnhuber HJ, et al.: Planetary Boundaries: Exploring the Safe Operating Space for Humanity. Ecology and Society 2009, 14.

5. FAO, IFAD, UNICEF, WFP, WHO: The State of Food Security and Nutrition in the World 2018. Building climate resilience for food security and nutrition. FAO; 2018.

6. Tzioumis E, Kay MC, Bentley ME, Adair LS: Prevalence and trends in the childhood dual burden of malnutrition in low- and middle-income countries, 1990-2012. Public Health Nutr 2016, 19:1375-1388.

7. IPCC: Global Warming of $1.5^{\circ} \mathrm{C} .2014$.

**8. van Bers C, Pahl-Wostl C, Ericksen PJ, Lenaerts L, Förch W, Korhonen-Kurki K, Methner N, Jones L, Vasileiou I, Ericksen S: Transformations in governance towards resilient food systems. 2016.

As a key review upon which this commentary is based, the article demonstrates through empirical studies, the key roles played by governance in food system transformation. It describes pre-conditions and the required processes for, as well as the outcomes of, transformations in governance, in terms of shifts in social relations and institutions.

9. Lang T, Barling D: Food security and food sustainability: reformulating the debate. The Geographical Journal 2012, 178:313-326.

10. Lang T, Barling D: Nutrition and sustainability: an emerging food policy discourse. Proceedings of the Nutrition Society 2013, 72:1-12.

*11. Hospes O, Brons A: Food System Governance: A Systematic Literature Review. In Amanda Kennedy \& Jonathan Liljeblad (eds.). Food Systems Governance: Challenges for Justice, Equality, and Human Rights. . Routledge; 2016.

12. Hawkes C, Friel S, Lobstein T, Lang T: Linking agricultural policies with obesity and noncommunicable diseases: A new perspective for a globalising world. Food Policy 2012, 37:343-353.

13. McMichael P: Food system sustainability: Questions of environmental governance in the new world (dis) order. Global Environmental Change 2011, 21:804-812.

14. Schilpzand R, Liverman D, Tecklin D, Gordon R, Pereira L, Saxl M, Wiebe K: Governance Beyond the State: Nonstate Actors and Food Systems. In Food Security and Global Environmental Change. Edited by Ingram J, Ericksen P, Liverman D. Routledge; 2012:272-300.

15. Lang T: Crisis? What Crisis? The Normality of the Current Food Crisis. Journal of Agrarian Change 2010, 10:87-97. 
16. Donkers H: Governance for Local and Regional Food Systems. Journal of Rural and Community Development $2013,8$.

17. Pereira LM, Ruysenaar S: Moving from traditional government to new adaptive governance: the changing face of food security responses in South Africa. Food Sec 2012, 4:41-58.

18. Glamann J, Hanspach J, Abson DJ, Collier N, Fischer J: The intersection of food security and biodiversity conservation: a review. Reg Environ Change 2017, 17:1303-1313.

19. FAO: World Food Summit: Rome Declaration and Plan of Action. 1996,

20. ... Liverman D, Kapadia K: Chapter 1 Food Systems and the Global Environment: An Overview. In Food Security and Global Environmental Change. Edited by Ingram J, Ericksen PJ, Liverman D. Routledge; 2012:3-24.

21. Challies E, Newig J, Lenschow A: What role for social-ecological systems research in governing global teleconnections? Global Environmental Change 2014, 27:32-40.

22. ........Fraser EDG, Mabee W, Figge F: A framework for assessing the vulnerability of food systems to future shocks. Futures 2005, 37:465-479.

**23. Ingram J, Ericksen P, Liverman D: Food Security and Global Environmental Change. Routledge; 2012.

This book describes how agriculture contributes to global environmental change, which is mainly through greenhouse gas emissions and land use change. It demonstrates the complexity involved in addressing the issue because of the influence of socioeconomic conditions on food systems, which are, in turn, influenced by a variety of processes such as macro-level economic policies and political conflicts.

24. Giupponi C, Gain AK: Integrated spatial assessment of the water, energy and food dimensions of the Sustainable Development Goals. Reg Environ Change 2017, 17:1881-1893.

*25. Eakin H, Rueda X, Mahanti A: Transforming governance in telecoupled food systems. Ecology and Society $2017,22$. This article uses the concept of telecoupling food systems to explore the evolution of governance and linkages in two case studies of coupled food systems.

26. Hodbod J, Eakin H: Adapting a social-ecological resilience framework for food systems. J Environ Stud Sci 2015, 5:474-484.

27. Bessa A: The Normative Dimension of Food Sustainability: A Human Rights-Based Approach to Food Systems Governance. Towards Food Sustainability. Centre for Development and Environment (CDE), University of Bern; 2019.

28. Eakin H, Connors JP, Wharton C, Bertmann F, Xiong A, Stoltzfus J: Identifying attributes of food system sustainability: emerging themes and consensus. Agric Hum Values 2017, 34:757-773.

29. Godfray HCJ, Beddington JR, Crute IR, Haddad L, Lawrence D, Muir JF, Pretty J, Robinson S, Thomas SM, Toulmin C: Food Security: The Challenge of Feeding 9 Billion People. Science 2010, 327:812-818.

30. Delaney A, Evans T, McGreevy J, Blekking J, Schlachter T, Korhonen-Kurki K, Tamás PA, Crane TA, Eakin H, Förch $\mathrm{W}$, et al.: Strengthening the food systems governance evidence base: Supporting commensurability of research through a systematic review of methods. CGIAR Research Program on Climate Change, Agriculture and Food Security (CCAFS); 2016.

**31. Delaney A, Evans T, McGreevy J, Blekking J, Schlachter T, Korhonen-Kurki K, Tamás PA, Crane TA, Eakin H, Förch W, et al.: Governance of Food Systems Across Scales in Times of Social-Ecological Change: A Review of Indicators. Food Security 2018, 10:287-310.

One of the reviews on which this commentary is based, this article analyzes the methods used to study the governance of food systems.

32. Aguilera RV, Rupp DE, Williams CA, Ganapathi J: Putting the S Back in Corporate Social Responsibility: A Multilevel Theory of Social Change in Organizations. The Academy of Management Review 2007, 32:836-863.

33. Dacin MT, Goodstein J, Scott WR: Institutional Theory and Institutional Change: Introduction to the Special

Research Forum. The Academy of Management Journal 2002, 45:45-56.

34. Wickert C, Vaccaro A, Cornelissen J: “Buying” Corporate Social Responsibility: Organisational Identity Orientation as a Determinant of Practice Adoption. J Bus Ethics 2017, 142:497-514.

35. Bizikova L, Echeverría D, Hammill A: Systematic review approach to identifying key trends in adaptation governance at the supranational level. CGIAR Research Programme on Climate Change Agriculture and Food Security (CCAFS); 2014.

36. .....Carr ER: Properties and projects: Reconciling resilience and transformation for adaptation and development. World Development 2019, 122:70-84.

37. Eriksen SH, Nightingale AJ, Eakin H: Reframing adaptation: The political nature of climate change adaptation. Global Environmental Change 2015, 35:523-533.

38. Khan MH: Markets, states and democracy: Patron-client networks and the case for democracy in developing countries. Democratization 2005, 12:704-724.

39. Smith MJ: Pluralism, Reformed Pluralism and Neopluralism: the Role of Pressure Groups in Policy-Making. Political Studies 1990, 38:302-322.

40. Montpetit É: In defense of pluralism: Policy disagreement and its media coverage. Cambridge University Press; 2016.

41. Steinberg PF: Can We Generalize from Case Studies? Global Environmental Politics 2015, 15:152-175.

42. Dodds A: Comparative Public Policy. 2018.

43. Abdulai A-G: The Political Economy of Regional Inequality in Ghana: Do Political Settlements Matter? Eur J Dev Res 2017, 29:213-229.

44. Abdulai A-G, Bawole JN, Sakyi EK: Rethinking Persistent Poverty in Northern Ghana: The Primacy of Policy and Politics over Geography. Politics \& Policy 2018, 46:233-262. 
45. ......... Blatter J, Haverland M: Cases Studies and (Causal-) Process Tracing. In Comparative Policy Studies: Conceptual and Methodological Challenges. Edited by Engeli I, Rothmayr C. Palgrave Macmillan; 2014:59-84.

46. Flyvbjerg B: Five Misunderstandings About Case-Study Research. Qualitative Inquiry 2006, 12:219-245.

47. .............. Mahoney J: Qualitative methodology and comparative politics. Comparative Political Studies 2007, 40:122-144.

48. Engeli I, Rihoux B, Rothmayr C: Intermediate-N Comparison: Configurational Comparative Methods. In

Comparative Policy Studies: Conceptual and Methodological Challenges. Edited by Engeli I, Rothmayr C. Palgrave Macmillan; 2014:85-108.

49. Marx A, Rihoux B, Ragin C: The origins, development, and application of Qualitative Comparative Analysis: the first 25 years. European Political Science Review 2014, 6:115-142.

50. Schneider CQ: Realists and Idealists in QCA. Political Analysis 2018, 26:246-254.

51. Schneider CQ, Wagemann C: Set-Theoretic Methods for the Social Sciences: A Guide to Qualitative Comparative Analysis.

Cambridge University Press; 2012.

52. Hall P: Systematic Process Analysis: when and how to use it. European Political Science 2008, 7:304-317.

53. ...............Purdon M: The Comparative Turn in Climate Change Adaptation and Food Security Governance Research. CGIAR Research Programme on Climate Change Agriculture and Food Security (CCAFS); 2014.

54. Purdon M, Thornton P: Research methodology for adaptation policy analysis: embracing the eclectic messy centre. In Research Handbook on Climate Change Adaptation Policy. Edited by Keskitalo ECH, Preston BL. Edward Elgar Publishing; 2019.

55. Engeli I, Rothmayr C (Eds): Comparative Policy Studies: Conceptual and Methodological Challenges. Palgrave Macmillan; 2014.

56. Mahoney J: Toward a Unified Theory of Causality. Comparative Political Studies 2008, 41:412-436.

57. Mahoney J: After KKV: The New Methodology of Qualitative Research. World Politics 2010, 62:120-147.

58. Ragin C: The Comparative Method: moving beyond qualitative and quantitative strategies. University of California Press; 1987.

59. Kissinger M, Rees WE, Timmer V: Interregional sustainability: governance and policy in an ecologically interdependent world. Environmental Science \& Policy 2011, 14:965-976.

60. Sikor T, Auld G, Bebbington AJ, Benjaminsen TA, Gentry BS, Hunsberger C, Izac A-M, Margulis ME, Plieninger T, Schroeder H, et al.: Global land governance: from territory to flow? Current Opinion in Environmental Sustainability 2013, 5:522-527.

61. Ostrom V, Tiebout CM, Warren R: The Organization of Government in Metropolitan Areas: A Theoretical Inquiry. The American Political Science Review 1961, 55:831-842.

62. McCord P, Dell'Angelo J, Baldwin E, Tom E: Polycentric Transformation in Kenyan Water Governance: A

Dynamic Analysis of Institutional and Social-Ecological Change. Policy Studies Journal 2016, 45:633-658.

63. Pahl-Wostl C, Knieper C: The capacity of water governance to deal with the climate change adaptation challenge: Using fuzzy set Qualitative Comparative Analysis to distinguish between polycentric, fragmented and centralized regimes. Global Environmental Change 2014, 29:139-154.

64. Sundkvist \AAsa, Milestad R, Jansson A: On the importance of tightening feedback loops for sustainable development of food systems. Food Policy 2005, 30:224-239.

65. Ostrom E: Polycentric systems for coping with collective action and global environmental change. Global Environmental Change 2010, 20:550-557.

66. Carlisle K, Gruby RL: Polycentric Systems of Governance: A Theoretical Model for the Commons. Policy Studies Journal 2017, doi:10.1111/psj.12212.

67. Oberlack C: Diagnosing institutional barriers and opportunities for adaptation to climate change. Mitig Adapt Strateg Glob Change 2017, 22:805-838.

68. McGinnis MD: An Introduction to IAD and the Language of the Ostrom Workshop: A Simple Guide to a Complex Framework. Policy Studies Journal 2011, 39:169-183.

69. Kimmich C: Linking action situations: Coordination, conflicts, and evolution in electricity provision for irrigation in Andhra Pradesh, India. Ecological Economics 2013, 90:150-158.

70. Lubell M: Governing Institutional Complexity: The Ecology of Games Framework. Policy Studies Journal 2013, 41:537-559.

71. Pingali PL: Green Revolution: Impacts, limits, and the path ahead. PNAS 2012, 109:12302-12308.

72. Yapa L: Improved seeds and constructed scarcity. In Liberation Ecologies: Environment, Development and Social Movements. Edited by Peet R, Watts M. Routledge; 1996.

73. Acemoglu D, Robinson JA: Why Nations Fail: The Origins of Power, Prosperity and Poverty. Crown Publishing; 2012.

74. Fraser EDG: Social Vulnerability and Ecological Fragility: Building Bridges between Social and Natural Sciences Using the Irish Potato Famine as a Case Study. Conservation Ecology 2003, 7.

75. Aklin M, Urpelainen J: Renewables: The Politics of a Global Energy Transition. MIT Press; 2018.

76. ....... Levin K, Cashore B, Bernstein S, Auld G: Overcoming the tragedy of super wicked problems: constraining our future selves to ameliorate global climate change. Policy Sci 2012, 45:123-152.

77. Bernstein S, Hoffmann M: The politics of decarbonization and the catalytic impact of subnational climate experiments. Policy Sci 2018, 51:189-211.

78. Lindblom CE: The Science of "Muddling Through.” Public Administration Review 1959, 19:79-88. 
79. Hall PA: Policy Paradigms, Social Learning, and the State: The Case of Economic Policymaking in Britain. Comparative Politics 1993, 25:275-296.

80. Cashore B, Howlett M: Punctuating Which Equilibrium? Understanding Thermostatic Policy Dynamics in Pacific Northwest Forestry. American Journal of Political Science 2007, 51:532-551.

81. Howlett M, Cashore PB: The Dependent Variable Problem in the Study of Policy Change: Understanding Policy Change as a Methodological Problem. Journal of Comparative Policy Analysis: Research and Practice 2009, 11:33-46.

82. Walker B, Carpenter S, Rockstrom J, Crépin A-S, Peterson G: Drivers, "Slow" Variables, "Fast” Variables, Shocks, and Resilience. Ecology and Society 2012, 17.

83. Walker B, Gunderson L, Kinzig A, Folke C, Carpenter S, Schultz L: A Handful of Heuristics and Some Propositions for Understanding Resilience in Social-Ecological Systems. Ecology and Society 2006, 11.

84. Cooper SJ, Wheeler T: Adaptive governance: Livelihood innovation for climate resilience in Uganda. Geoforum 2015, 65:96-107.

85. Hoppe R: Lindblom on incrementalism: the tragic dilemma between understanding and shaping the world. European Policy Analysis 2017, 0.

86. Lebel L, Anderies J, Campbell B, Folke C, Hatfield-Dodds S, Hughes T, Wilson J: Governance and the Capacity to Manage Resilience in Regional Social-Ecological Systems. Ecology and Society 2006,

87. Gupta J: The multi-level governance challenge of climate change. Environmental Sciences 2007, 4:131-137.

88. Eakin H, Eriksen S, Eikeland P-O, Øyen C: Public sector reform and governance for adaptation: implications of new public management for adaptive capacity in Mexico and Norway. Environmental management 2011, 47:338-351. 89. Jacobi J, Schneider M, Mariscal MP, Huber S, Weidmann S, Bottazzi P, Rist S: Farm Resilience in Organic and Nonorganic Cocoa Farming Systems in Alto Beni, Bolivia. Agroecology and Sustainable Food Systems 2015, 39:798-823. 90. Termeer CJAM, Dewulf A, Breeman G, Stiller SJ: Governance Capabilities for Dealing Wisely With Wicked Problems. Administration \& Society 2013, 47:680-710.

91. Candel JJL, Breeman GE, Termeer CJAM: The European Commission's ability to deal with wicked problems: an in-depth case study of the governance of food security. Journal of European Public Policy 2015, doi:10.1080/13501763.2015.1068836.

92. Charli-Joseph L, Siqueiros-Garcia JM, Eakin H, Manuel-Navarrete D, Shelton R: Promoting agency for socialecological transformation: A transformation-lab in the Xochimilco social-ecological system. Ecology and Society 2018, 23:46.

93. ....Paschen J-A, Ison R: Narrative research in climate change adaptation-Exploring a complementary paradigm for research and governance. Research Policy 2014, 43:1083-1092.

94. Armendáriz V, Armenia S, Atzori AS: Systemic Analysis of Food Supply and Distribution Systems in City-Region Systems-An Examination of FAO's Policy Guidelines towards Sustainable Agri-Food Systems. Agriculture 2016, 6:65.

95. Blekking J, Tuholske C, Evans T: Adaptive Governance and Market Heterogeneity: An Institutional Analysis of an Urban Food System in Sub-Saharan Africa. Sustainability 2017, 9:2191.

96. Papaoikonomou E, Ginieis M: Putting the farmer's face on food: governance and the producer-consumer relationship in local food systems. Agric Hum Values 2017, 34:53-67.

97. Rossi A: Beyond Food Provisioning: The Transformative Potential of Grassroots Innovation around Food. Agriculture 2017, 7:6.

98. Smit W: Urban governance and urban food systems in Africa: Examining the linkages. Cities 2016, 58:80-86. 